\title{
Experimental study on the flexural behavior of large- scale rectangular concrete-filled steel tubular beams
}

\section{Estudo experimental sobre o comportamento à flexão de vigas de aço tubulares retangulares preenchidas com concreto em larga escala}
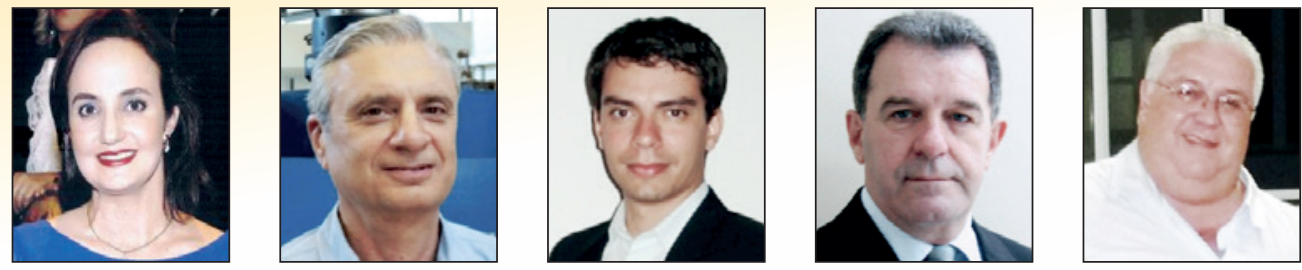

J. M. FLOR a

flor@dees.ufmg.br

R. H. FAKURY a fakury@dees.ufmg.br

R. B. CALDAS a caldas@dees.ufmg.br

F. C. RODRIGUES a

francisco@dees.ufmg.br

A. H. M. ARAÚJO afonso.araujo@vallourec.com

\section{Abstract}

This paper presents a series of test results of large-scale rectangular concrete-filled steel tubular (CFST) beams to explore their performance under pure bending. Concrete-filling tests were initially carried out on two beam specimens of 12-m in length to investigate the feasibility of casting horizontally large-scale rectangular tubes. A total of six 6-m long specimens were subjected to flexural test afterward, including four CFST beams and two steel hollow section (SHS) beams for comparison. The test results showed that the rectangular CFST beams behaved in a relatively ductile manner. The concrete infilling enhanced the flexural behavior and performance of the steel tubes. Finally, the rigid-plastic theory showed suitable to predict the moment capacity of CFST compact beams.

Keywords: concrete filled steel tube, rectangular section, beam, pure bending, moment capacity.

\section{Resumo}

Este artigo apresenta uma série de resultados de ensaios experimentais executados em vigas mistas de aço tubulares retangulares preenchidas com concreto (VMPC) em larga escala para se estudar o comportamento à flexão pura. Inicialmente, foram realizados testes de concretagem em dois protótipos de $12 \mathrm{~m}$ de comprimento para se investigar a viabilidade executiva do preenchimento com concreto de tubos de aço retangulares em larga escala posicionados horizontalmente. Na sequência, seis protótipos de $6 \mathrm{~m}$ de comprimento foram submetidos ao ensaio de flexão, incluindo quatro VMPC retangulares e duas vigas puramente de aço tubulares retangulares (VA) para comparação. Os resultados dos ensaios mostraram que as VMPC retangulares apresentaram comportamento à flexão relativamente dúctil. O preenchimento de concreto melhorou o comportamento à flexão e o desempenho dos tubos de aço. Finalmente, a teoria rígido-plástica apresentou-se adequada para se estimar a capacidade resistente ao momento fletor de VMPC retangulares compactas.

Palavras-chave: tubo de aço preenchido com concreto, seção retangular, viga, flexão pura, capacidade resistente ao momento fletor.

Departamento de Engenharia de Estruturas, Escola de Engenharia, Universidade Federal de Minas Gerais, Belo Horizonte, MG, Brazil;

Vallourec Research Center Brasil, Vallourec Tubos do Brasil, S.A., Belo Horizonte, MG, Brazil. 


\section{Introduction}

The association of steel and concrete to build structural composite beams for buildings has evolved along the years. Initially, steel sections were encased in non-structural concrete to enhance their fire resistance. After concretes with higher mechanical properties became more readily available, design engineers realized the advantages of considering its contribution to the flexural capacity of the beams, establishing the steel-concrete composite beams (Figure 1a). Within this initial concept of composite beams, the steel-concrete interaction relied exclusively on the adherence along the interface between the components. The development of fire-resistant coating materials made the concrete encasement of the steel profile unnecessary and new concepts of composite beams have been proposed including the one in which a concrete slab (either a solid or a composite slab) is placed on top of the steel section, usually an I-section profile. The composite action is established by shear connectors such as headed stud connectors (Figure 1b). Partially-encased beams, i.e., beams in which the web of the steel profile is encased by reinforced concrete and shear connection is provided between the concrete and the steel components are also employed in Europe and their design is guided by EN 1994-1-1:2004 [1]. A concrete or composite slab can also form

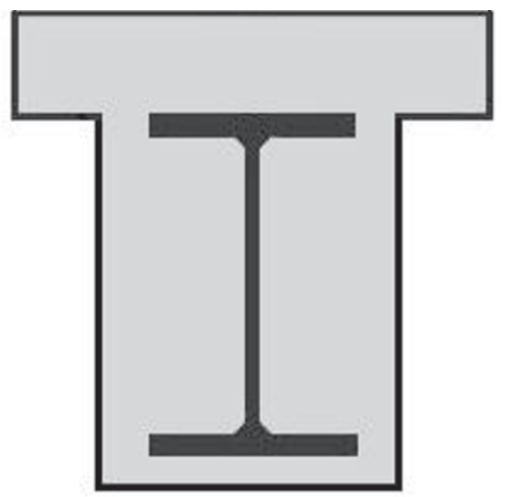

A)

Concrete-encased section

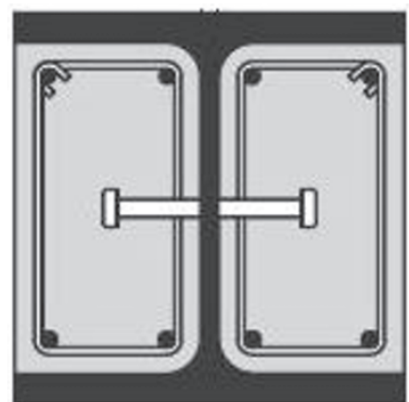

Partially encased section without slab

Figure 1

Typical steel-concrete composite beam cross-sections part of the effective section of the composite beam, provided that it is attached to the steel section by a shear connection (Figures $1 \mathrm{c}$ and 1d).

More recently, engineers realized the advantages of filling steel hollow sections with concrete (Han et al. [2]). Concrete-filled steel tubular (CFST) columns show enhanced structural performance over either a steel column or a reinforced concrete column due to the confinement of the concrete provided by the steel tube and to the lateral support of the steel tube provided by the concrete core, i.e., local buckling of the steel tube is delayed due to the restraining effect of the concrete. Additional advantages of this type of CFST column system include (i) construction efficiency due to the elimination of formwork, besides the reduction in manpower, construction cost and construction time, (ii) fire resistance improved by the infilled concrete, and (iii) reduced environmental impact by omitting the formwork.

Over the last decades, some studies have been carried out on the flexural behavior of CFST members under pure bending (Lu and Kennedy [3]) (Elchalakani et al. [4]) (Gho and Liu [5]) (Han [6]) (Han et al. [7]) (Lu et al. [8]) (Moon et al. [9]) (Jiang et al. [10]) (Wang et al. [11]). The studies demonstrated the increase in ductility and showed the enhancement in flexural capacity of the composite

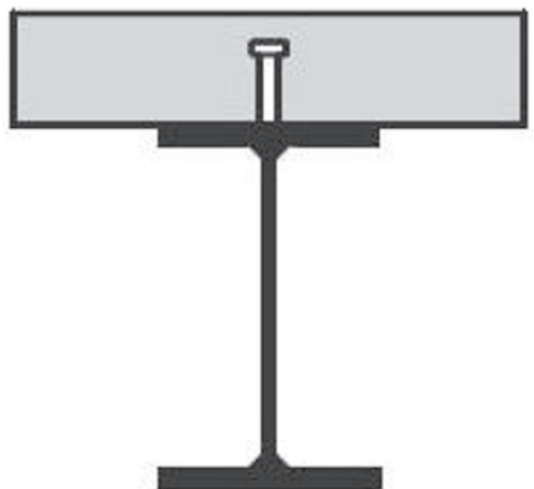

B Composite section with slab

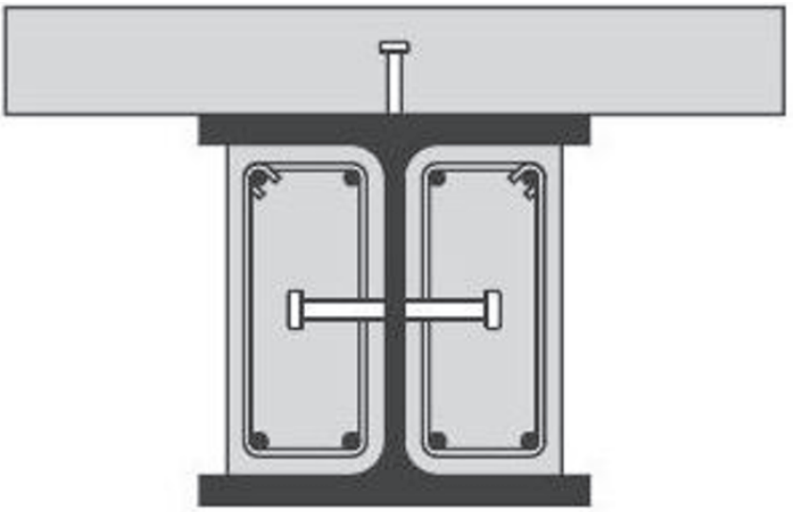

D Partially encased section with slab 
beams over that of steel hollow sections. The main parameters investigated include (i) cross-section type and dimensions of the steel tube, (ii) material specifications for both steel and concrete, (iii) shear span to depth ratio, within others. However, previous experimental research work limited their scope to reduced-scale prototypes. In general, specimen lengths were within the 1000$2000 \mathrm{~mm}$ range. Furthermore, concrete was poured vertically into the steel tube. Few researchers reported a very small amount of longitudinal shrinkage at the top of the specimens during curing. In such cases, high-strength epoxy (Han [6]) or high-strength cement mortar (Gho and Liu [5]) (Jiang et al. [10]) was used to fill this longitudinal gap. The gap between steel tube and concrete core has been recognized as a type of initial concrete imperfection in CFST circular members (Liao et al. [12]). Circumferential gaps may be caused by the concrete shrinkage and usually appears in vertical elements. On the other hand, spherical-cap gaps may occur in horizontal members due to the constructional process.

Within this context, an extensive experimental research project on large-scale rectangular CFST beams has been undertaken at the Federal University of Minas Gerais (UFMG) since 2012. The first phase of the project examined an adequate concrete mix and a feasible and efficient concrete-filling process to cast horizontally large-scale steel tubes to promote their applicability as composite beams in buildings with tubular structures. The second phase focused on the investigation of the flexural behavior of large-scale rectangular CFST beams subjected to pure bending test. A total of ten 6000-mm-long specimens, including eight ordinary CFST beams and two CFST beams with a solid concrete slab attached to the steel tubular section by shear connection, were tested in the program. The third phase comprises a numerical finite element modeling of the CFST beams to further investigate their flexural behavior through a parametric study. The fourth and last phase includes an analytical study to provide the Brazilian standard with the necessary support to guide the design of CFST beams.

The main objectives of this paper are threefold: (1) to report a series of concrete-filling tests performed on large-scale rectangular tubes in the horizontal position; (2) to present the initial results of large-scale rectangular SHS and CFST beams subjected to pure bending test; and (3) to evaluate the rigid-plastic theory to predict the moment capacity of CFST beams within the limited scope of this research project.

\section{Experimental investigation}

The experimental study was performed to evaluate the feasibility and quality of casting large-scale rectangular tubes in the horizontal position and to investigate the behavior of the rectangular CFST beams. Experiments on steel hollow specimens were also conducted for comparison. The following sections provide detailed description of the test specimens and parameters, materials, and procedures.

\subsection{Test specimens and parameters}

Two 12-m long SHS specimens were tested under two different methods to pour the concrete into the tubes and six 6-m long beams were tested under pure bending. Both concrete-filling tests

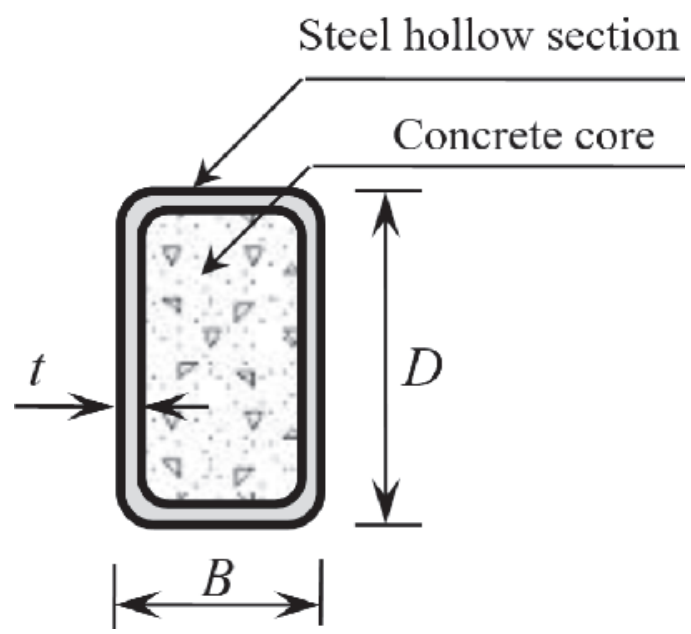

Figure 2

Rectangular CFST cross-section

and flexural tests were carried out in the Experimental Structural Analysis Laboratory (LAEEs) at UFMG.

The main parameters in the tests are: For the concrete-filling tests: pouring method: with and without pressure. For the flexural tests: (1) cross-sectional type: hollow and concrete-filled sections; (2) steel-concrete interface: with and without treatment. The following identifications are used to characterize each specimen: The initial two characters "CF" or PB" stand for concrete-filling or pure bending test, the second character "R" stands for the rectangular section; the last character "H" or "C" stands for the hollow or composite section; the first Arabic numeral stands for the group number for a specimen type, and the second Arabic number stands for the order of specimens within that group. For example, the specimen with the label "PB-RC1-2" denotes the second specimen in the first group of the rectangular composite beam tested under pure bending. The parameters of the specimens in the test series are shown in Figure 2 and listed in Table 1, where "D" and "B" are the depth (height) and breadth (width) of the rectangular steel tube, respectively; " $\mathrm{t}$ " is the rectangular steel tube wall thickness and "L" is the total length. To maintain a means of direct comparison,

\section{Table 1}

Summary of rectangular test specimens

\begin{tabular}{|c|c|c|c|}
\hline $\mathbf{N}^{\circ}$ & $\begin{array}{c}\text { Specimen } \\
\text { designation }\end{array}$ & $\begin{array}{c}\text { Cross-section } \\
\mathbf{D} \times \mathbf{B} \times \mathbf{~} \mathbf{( m m})\end{array}$ & $\begin{array}{c}\mathbf{L} \\
(\mathbf{m m})\end{array}$ \\
\hline 1 & CF-R1-1 & $250 \times 150 \times 6.4$ & 12000 \\
\hline 2 & CF-R1-2 & $250 \times 150 \times 6.4$ & 12000 \\
\hline 3 & PB-RH1-1 & $250 \times 150 \times 6.4$ & 6000 \\
\hline 4 & PB-RH1-2 & $250 \times 150 \times 6.4$ & 6000 \\
\hline 5 & PB-RC1-1 & $250 \times 150 \times 6.4$ & 6000 \\
\hline 6 & PB-RC1-2 & $250 \times 150 \times 6.4$ & 6000 \\
\hline 7 & PB-RC2-1 & $250 \times 150 \times 6.4$ & 6000 \\
\hline 8 & PB-RC2-2 & $250 \times 150 \times 6.4$ & 6000 \\
\hline
\end{tabular}




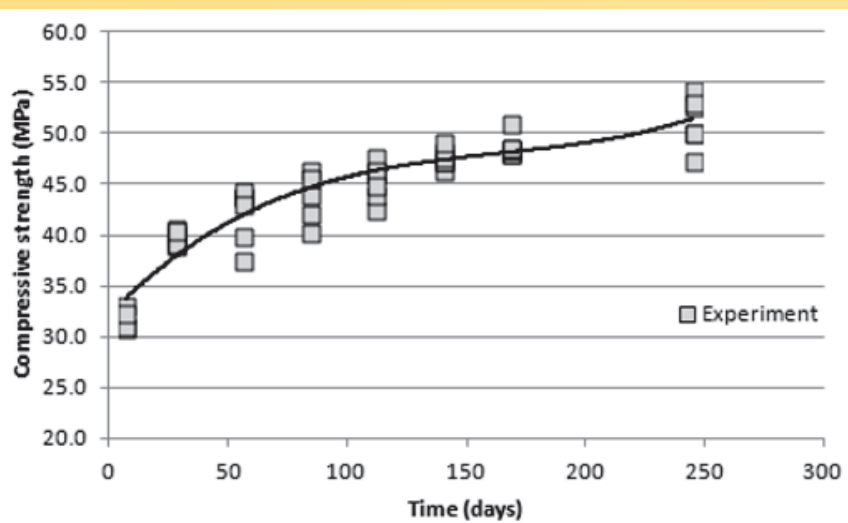

Figure 3

Concrete strength with time

all the specimens had the same cross-sectional dimensions. The breadth to depth ratio (B/D) and the effective breadth (width) to wall thickness ratio (b/t) are 0.60 and 18.44 respectively. The external corner radius (outer radius) "ro" was taken as $2.5 \mathrm{t}$.

It is worth mentioning that, under bending, circular hollow steel tubes do not show the same performance as under axial compression. In fact, rectangular tubes perform much better than circular tubes to support flexural efforts. Although less efficient than open section steel profiles when subjected to bending, rectangular hollow sections provide to the building a clean and pleasantly aesthetic appearance. Finally, the present study is an attempt to investigate the concrete in-filling and the flexural behavior of rectangular CFST beams with reduced cross-sectional dimensions and longer span which are representative of typical situations in practice of tubular steel structures.

\subsection{Materials}

Steel tubes with nominal yield strength of $300 \mathrm{MPa}$ and nominal ultimate strength of $415 \mathrm{MPa}$ were used in the tests. Tensile coupons were tested to determine the actual steel properties. The average yield strength $\left(f_{\mathrm{y}}\right)$ and the ultimate strength $\left(f_{\mathrm{u}}\right)$ are $373 \mathrm{MPa}$ and $515 \mathrm{MPa}$, respectively. The modulus of elasticity $\left(E_{\mathrm{s}}\right)$ is $192.5 \mathrm{GPa}$. The composite tubular beams were designed to be filled with normal strength and normal weight concrete. Due to the rheological characteristics of self-consolidating concrete (SCC), especially the ability to flow under its own weight and fill in the formwork in cast processing without the use of vibration, it was considered to be the most appropriate concrete to be employed in this investigation. Ready-mix

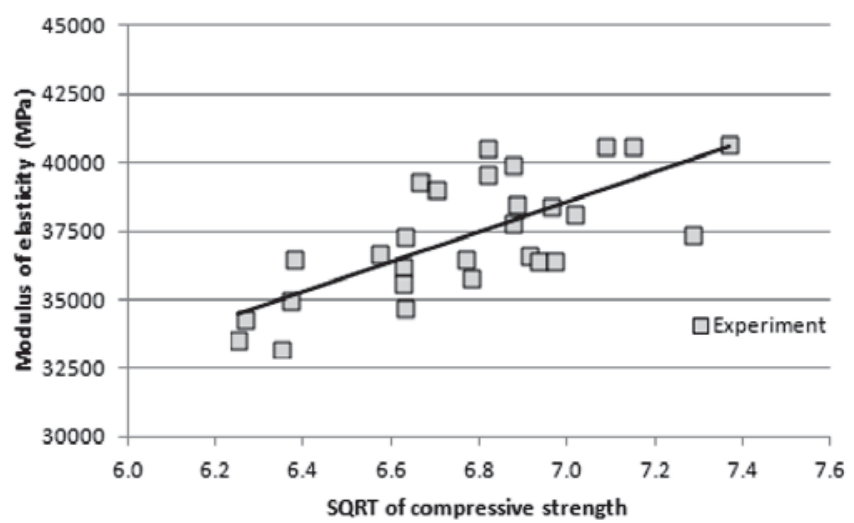

\section{Figure 5}

Modulus of elasticity versus square-root of compressive strength

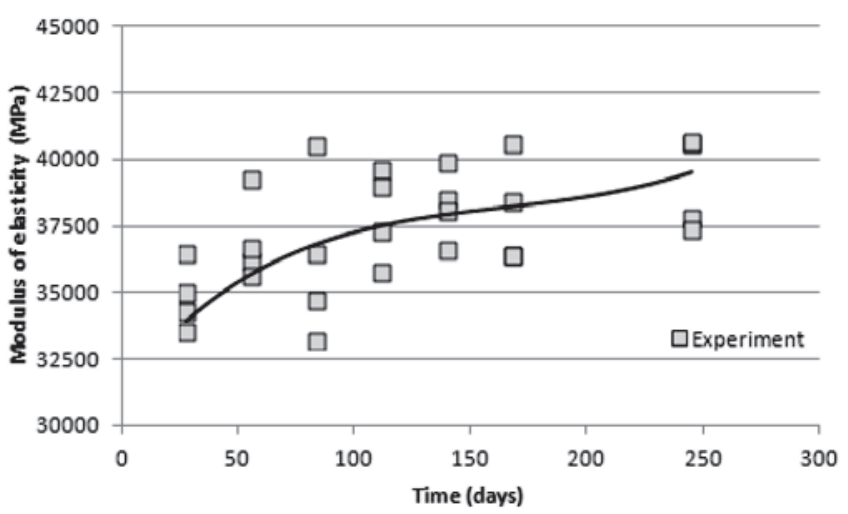

Figure 4

Modulus of elasticity with time

SCC, designed with compressive cylinder strength at 28 days of 30 $\mathrm{MPa}$ was used to cast the test specimens. According to the Brazilian standard ABNT NBR 15823-1:2010 [13] the following technical requirements were specified to the SCC mix: slump flow within the range of 660-750 mm; viscosity superior to 2 seconds (evaluated by monitoring the time it takes for the concrete to reach a spread of 500 $\mathrm{mm}$ ); and ability to flow through reinforcement within the range of 0-25 $\mathrm{mm}$ (evaluated by using the J-ring apparatus).

Standard $100 \mathrm{~mm} \times 200 \mathrm{~mm}$ concrete cylinders were prepared from the single batch used for all pure bending test specimens. After casting, the cylinders were kept in the molds under curing conditions similar to those of the beam specimens. Both ends of the concrete cylinders were ground flat immediately before testing. The concrete cylinders were tested at different ages along the duration of the study to determine the compressive strength, in accordance with ABNT NBR 5739:2007 [14], and the modulus of elasticity, in accordance with ABNT NBR 8522:2008 [15]. Figure 3 and Figure 4 show, respectively, the variation of the compressive strength $\left(f_{c}\right)$ and of the modulus of elasticity $\left(E_{c}\right)$ with time.

The compressive strength of the concrete at the time the flexural tests were done was determined by using a least-squares regression to the test data. The third-degree polynomial function obtained is given by Equation (1) and its curve is shown in Figure 3.

$f_{\mathrm{c}}=2,6203 \times 10^{-6} \times t^{3}-0,0013 \times t^{2}+0,2385 \times t+32,2022$

The experimental values of the modulus of elasticity at each age were plotted against the values of square-root of its corresponding compressive strength as shown in Figure 5. A least-squares regression was used to fit a straight-line model to the data, with intercept set to zero. The function is given by Equation (2) and its linear curve is shown in Figure 5. The curve obtained by combining Equation (2) with Equation (1) is shown in Figure 4.

$E_{\mathrm{c}}=5512,13 \times \sqrt{f_{\mathrm{c}}}$

It should be noted that a finite element analysis of CFST beams shall be conducted in the near future and a parametric study shall be used to investigate the influence of important parameters, including cross-section dimensions and materials properties, on the flexural performance of the composite beams.

\subsection{Concrete-filling tests}

Concrete-filling tests were conducted on two 12000-mm long specimens. Due to the lack research on casting procedures of real- 


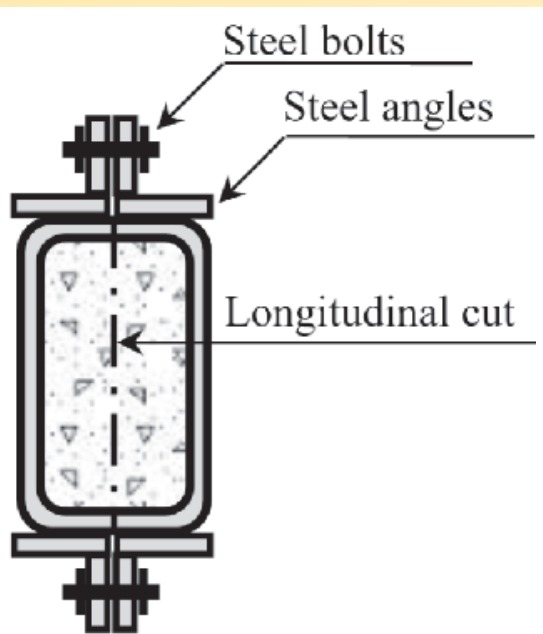

Figure 6

Concrete-filling test specimen cross-section

scale CFST beams positioned horizontally, two methods were proposed and investigated: one that uses pressure to pour concrete into the tube and one that fills the tube with no pressure.

Both specimens were designed to have a circular, $100 \mathrm{~mm}$ in diameter hole on the top flange at both ends of the steel tube. Additionally, both specimens were manufactured with a longitudinal cut throughout the entire length, splitting the tube into two halves, in order to facilitate mold releasing for visual inspection of the infilled concrete. At every meter along the length of the tube, two steel angles $(75.6 \times 75.6 \times 6.3 \times 75 \mathrm{~mm})$ were welded both on the top and bottom flanges and fastened together with steel bolts to keep the specimen closed during casting and curing period, as shown in Figure 6. Specimens were capped at both ends with a 6.3-mm thick rectangular steel plate $(250 \mathrm{~mm} \times 300 \mathrm{~mm})$ fastened to two steel angles $(75.6 \times 75.6 \times 6.3 \times 210 \mathrm{~mm})$ welded on the outer surface of the webs of the tube. During manufacture, the outer and inner surfaces of the steel tubes were painted with a red protective coating to avoid corrosion and to facilitate demolding. Before casting, the inner surface of the specimens was also treated with a thick coat of wax-based mold release agent proper for metallic formwork to prevent concrete from bonding to the steel surface. Finally, silicone sealant was used to seal every joint or gap along the longitudinal cut and along the contact perimeter between the steel plate and the steel tube at both ends of each specimen so to avoid cement paste leakage. Figure 7 shows a photo of both specimens before casting.

Both specimens were horizontally filled with SCC without any vibration. Two different apparatus were designed to be coupled to the tube at one of its circular holes during casting: a PVC funnel and a metallic device, as shown in Figure 8. The former was used for casting one

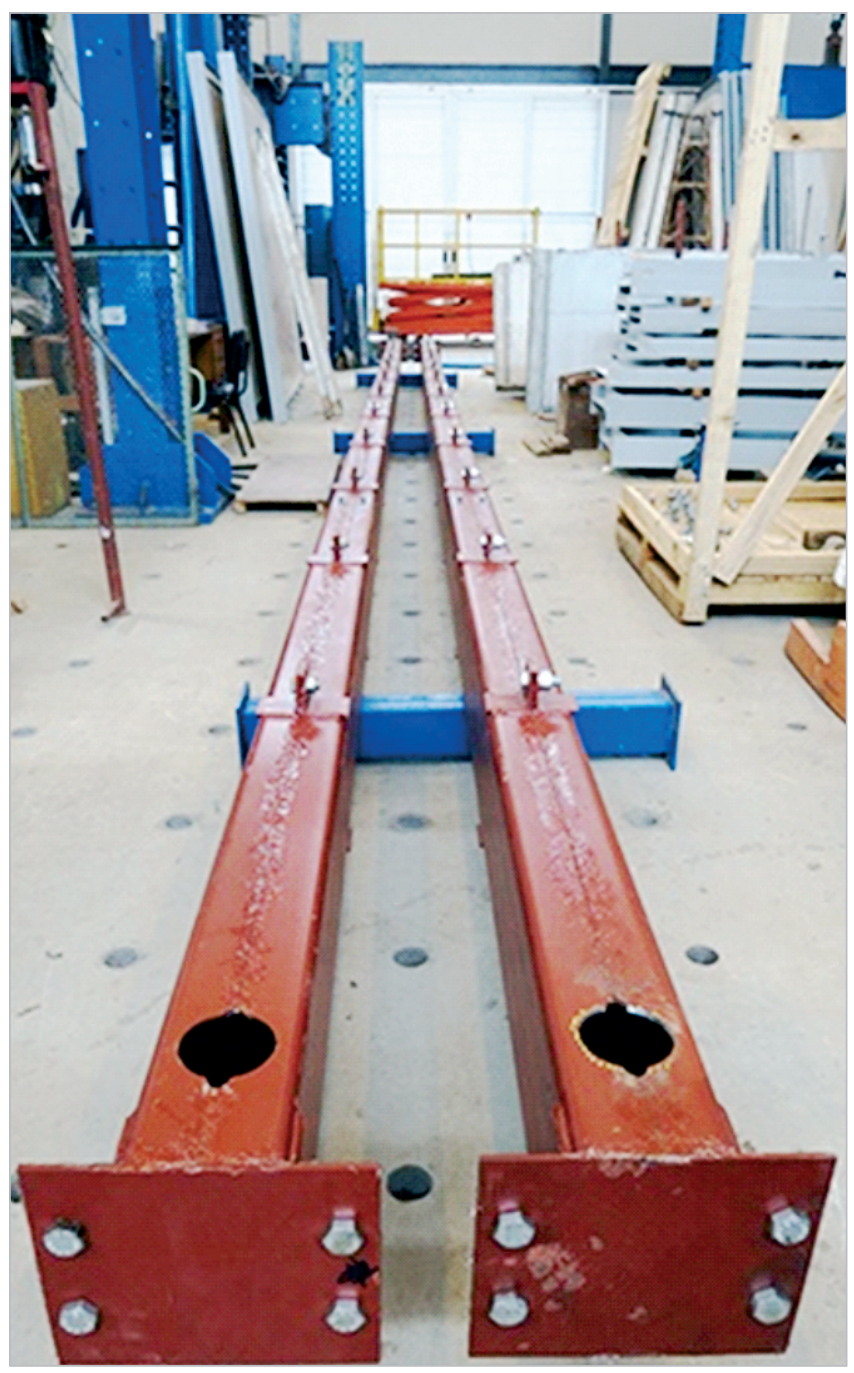

Figure 7

Concrete-filling test specimens before casting

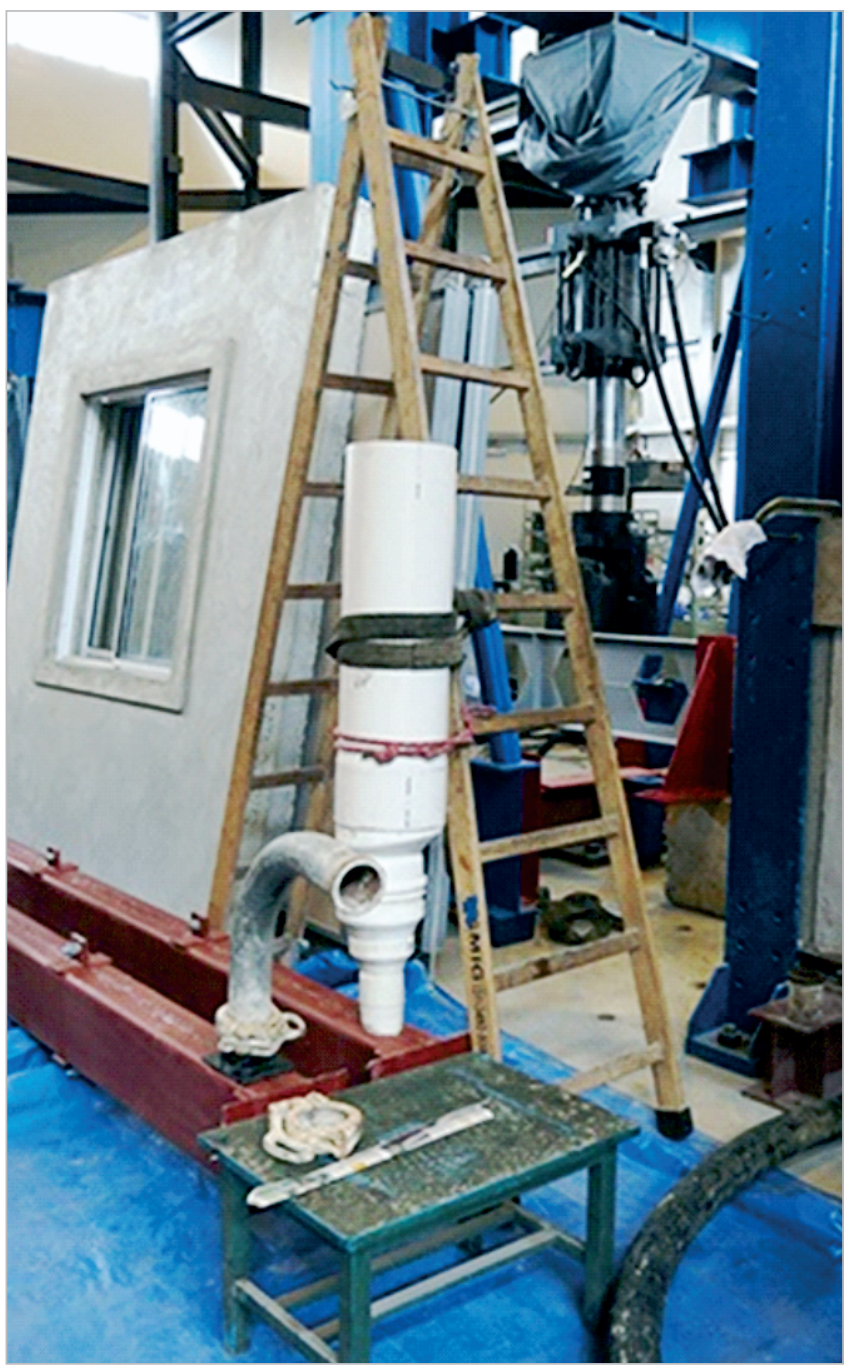

Figure 8

Concrete-filling test apparatus 


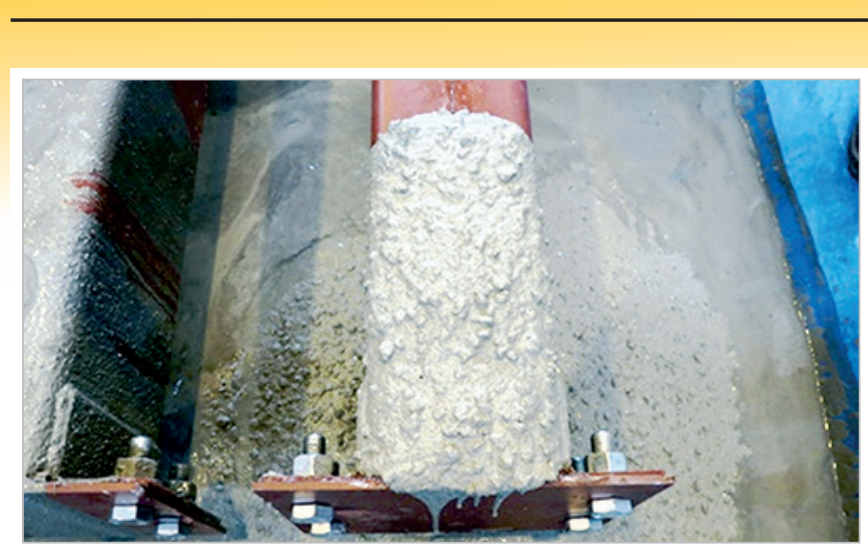

Figure 9

Concrete overflow

specimen under no pressure condition. The later was used for casting the other specimen under pressure condition. In this case, the concrete was pumped into the tube through a hose that was manually attached to the metallic device already fixed to the tube. The duration of each concrete-filling test, i.e., the time period between the start of concrete injection inside the tube at one end of the specimen and the start of concrete overflow at the other end was 3 minutes, approximately (Figure 9). After casting, the CFST specimens were kept undisturbed until they were opened for visual inspection of the infilled concrete.

Both casting procedures were considered successful and efficient in filling completely the interior of the $12-\mathrm{m}$ long tubes. Due to its lower height, ease of use and fast coupling to the tube, the metallic device showed to be an excellent solution to facilitate the injection of concrete inside the tube in the field.

Specimens were opened approximately eight months after casting for visual inspection of the infilled concrete. Figure 10 presents the mold releasing process. It was possible to macroscopically detect innumerous discontinuities or "gaps" of different sizes, shapes and depth on the top surface as shown in Figure 11. The depth of the gaps was evaluated along the specimen entire length. In average, gaps were 1.97-mm and 2.99-mm deep for the specimen filled with the PVC funnel (without pressure) and the metallic device (with pressure), respectively. These observations corroborate previous literature findings regarding initial concrete imperfections due to construction process in circular CFST members (Liao et al. [12]).

\subsection{Pure bending tests}

Pure bending tests were conducted on six 6000-mm long specimens. Similarly to the concrete-filling tests specimens, these specimens had circular holes at both ends so to allow pouring concrete into the

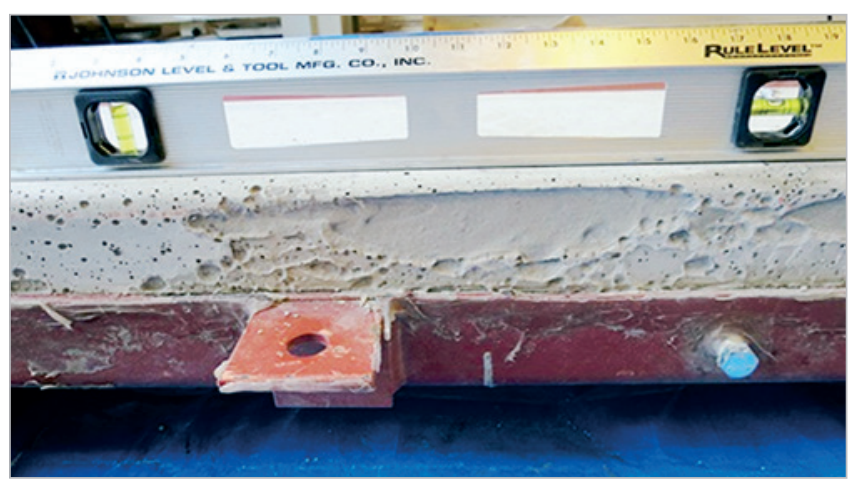

Figure 11

Discontinuities on the concrete core

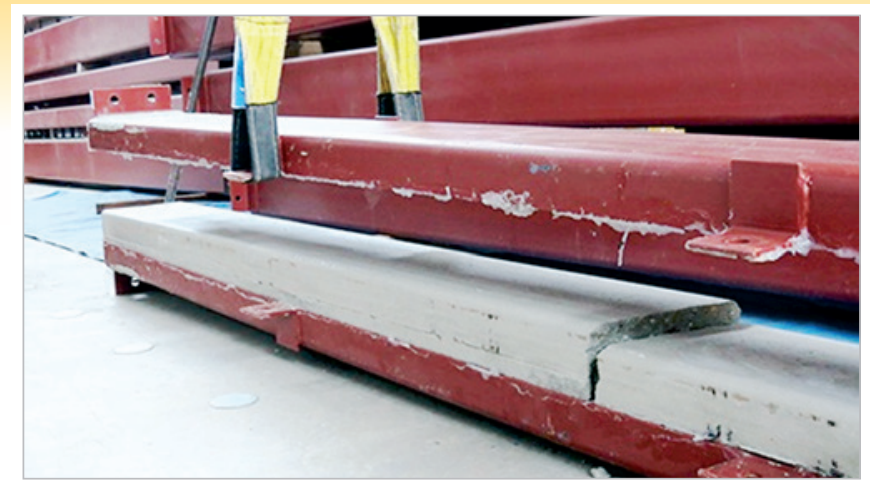

Figure 10

Specimen mold releasing

steel tube. The outer surface of the all tubes was also painted with the same red anti-corrosive protective coating. However, the inner surface received no treatment; exception only to the specimens in the first group of the rectangular composite beams, i.e., specimens PB-RC1-1 and PB-RC1-2. Besides the protective coating, the inner surface was also treated with a thick wax-based coating. These two specimens were specially prepared to minimize the adherence between the steel tube and the concrete core. Minimum adherence throughout the steel-concrete interface was believed to be the worst case scenario for the composite action of the steel tube and the concrete core. The four rectangular composite beam specimens were horizontally filled with concrete under pressure condition based on the effectiveness and the efficiency of this casting procedure observed previously through the concrete-filling tests. The ends of the composite beam specimens were capped with steel plates to retain the concrete when they were cast in the horizontal position. They were kept capped until the flexural test. Prior to the test, the end plates were removed from the composite beam specimens to allow slip to occur between the concrete core and the steel tube. This was believed to be the worst case in regards to loss of composite action. A schematic diagram of the flexural test setup and instrumentation is given in Figure 12 and a general view of the test is shown in Figure 13. The specimen was simply supported on two rigid steel beams. The load was applied by a $1500 \mathrm{kN}$ capacity MTS actuator through a rigid steel beam with four-point loading. By using this loading configuration, a zone of constant bending moment and zero shear force is generated between the loading points. In Figure 12 , " $L$ 。" denotes the effective length of the beam $(5700 \mathrm{~mm})$ and "a" denotes the shear span, taken as one third of the effective length $(1900 \mathrm{~mm})$. The shear span-to-depth ratio was 7.6.

One displacement transducer (DT) was installed at the mid-span sec-

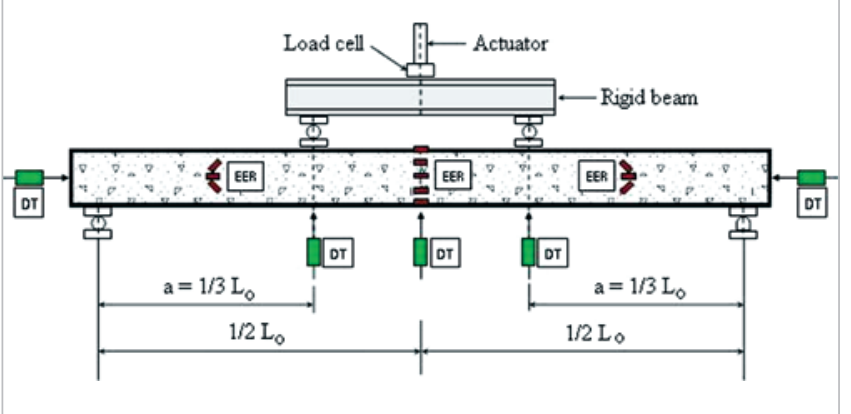

Figure 12

Flexural test setup 
tion and another two at the loading point sections to measure vertical in-plane displacements. Two other DTs were also installed at both ends of the CFST beams specimens to measure horizontal displacements. The relative slip between the steel tube and the concrete core was measured at the center of the section. In order to monitor the longitudinal deformation of the specimens, electric resistance strain gauges (SGs) were bonded on the steel outer surface of the midspan section: two at the top (upper flange), two at the bottom (lower flange), and five equally distributed at one lateral face (anterior web). During the test, the strains readings and the displacement measurements were recorded in a LYNX acquisition system. The loading script was managed by the MTS system. Each specimen was tested under monotonic bending about the major axis until either failure or noticeable ultimate moment capacity was reached.

\subsection{Experimental results}

Figure 14 shows the measured bending moment vs. mid-span
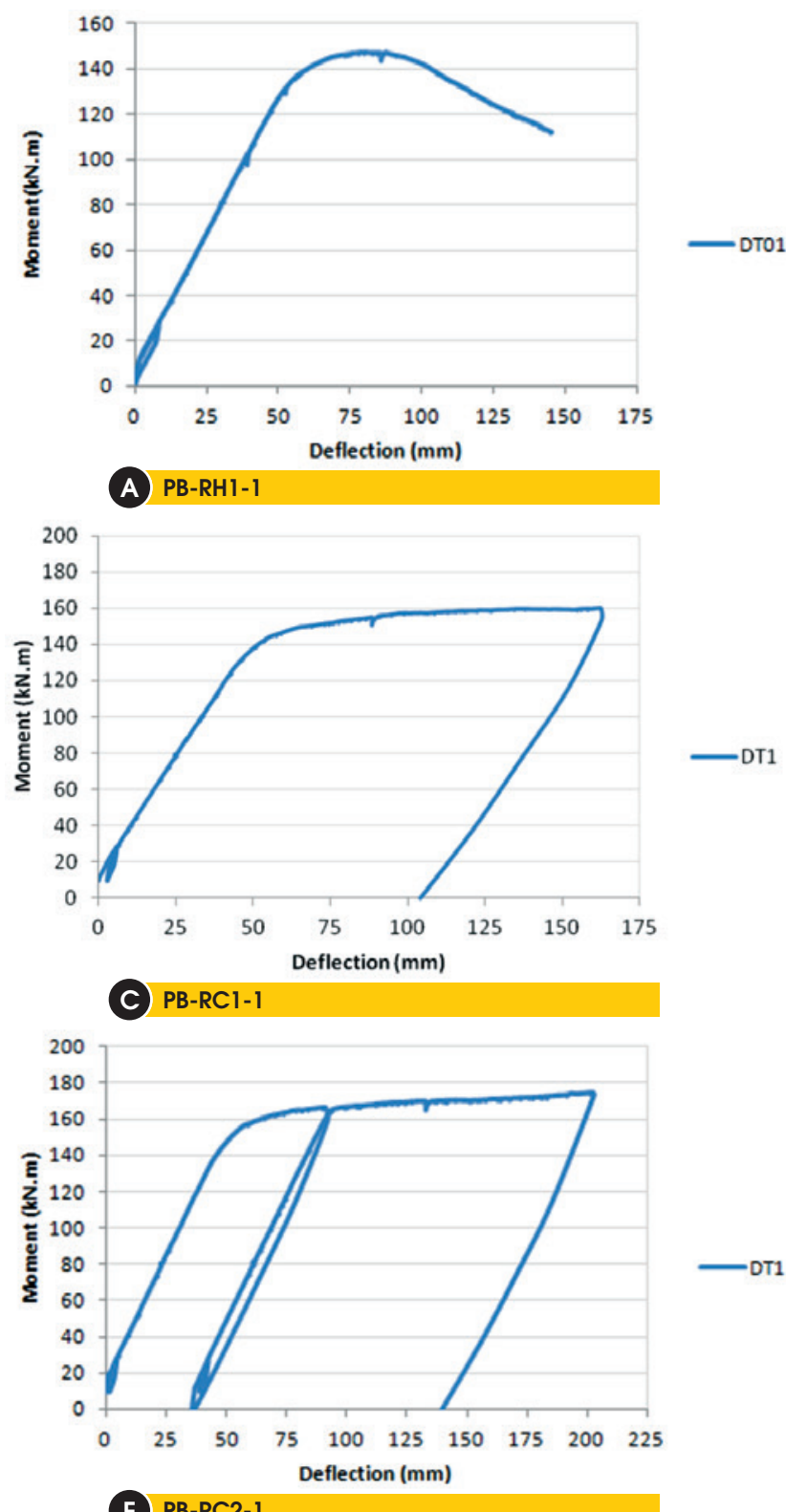

E PB-RC2-1

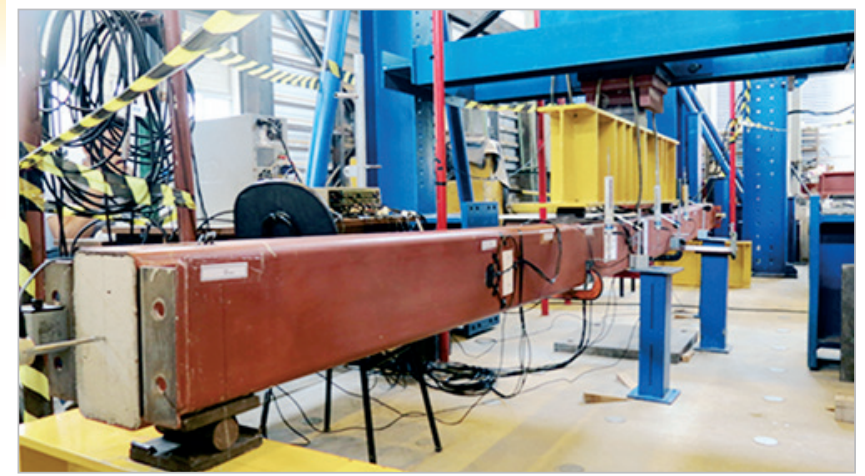

Figure 13

Flexural test view

deflection graph for each beam specimen. The diagrams obtained for the unfilled SHS specimens (series PB-RH1) show that there is

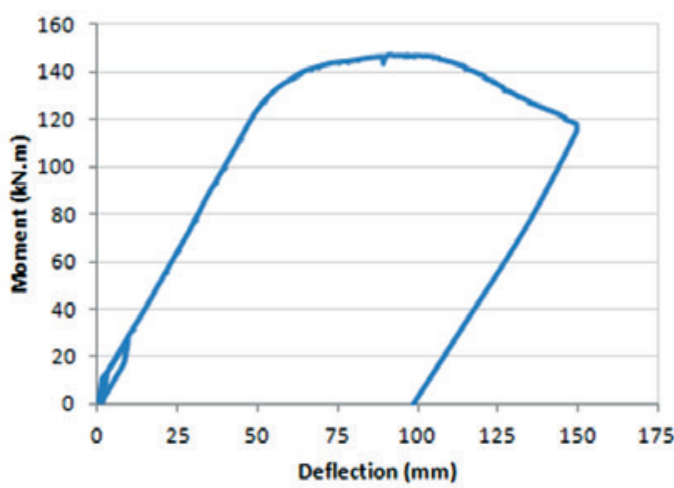

\section{B $\mathrm{PB}-\mathrm{RHI}-2$}

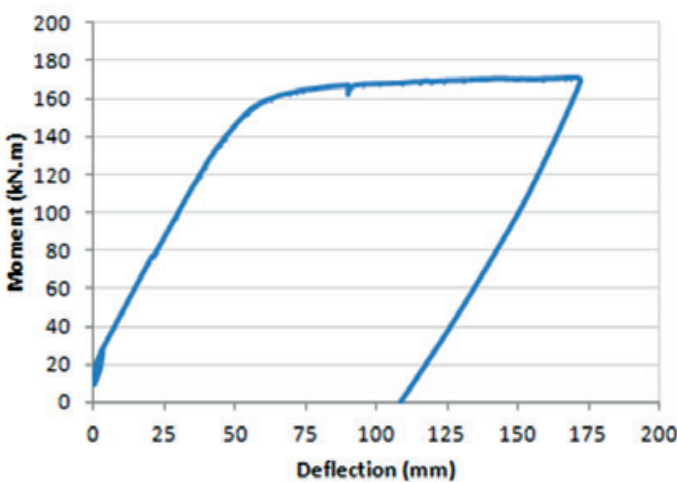

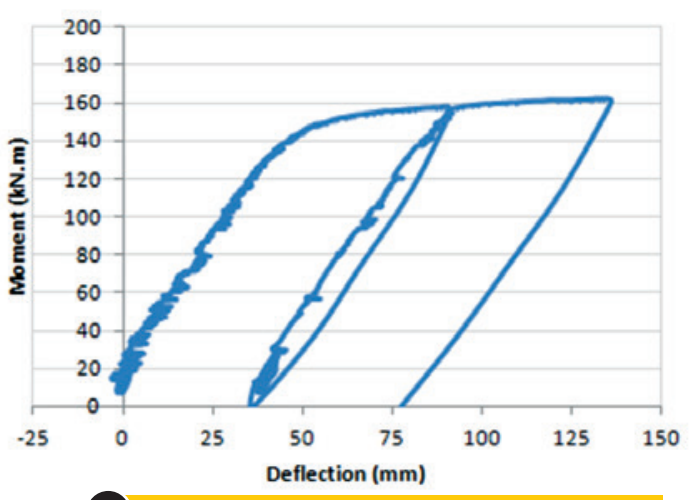

Figure 14

Moment vs. mid-span deflection of beam specimens 
PB-RH1-1

Figure 15

Failure mode of unfilled SHS specimens

an initial elastic response, and then an inelastic behavior with gradually decreasing stiffness until the maximum moment is reached. The post-peak behavior is characterized by the descendent branch of the curve. Both SHS specimens failed due to a plastic inward ripple exhibited in the compressive area of the specimen underneath the loading point as shown in Figure 15. For the CFST specimens (series PB-RC1 and PB-RC2), the existence of the inner concrete core changed the flexural behavior of the outer steel tube. The corresponding diagrams show that there is an initial elastic stage followed by an inelastic stage with gradually decreasing stiffness, until the ultimate moment is approached asymptotically. The tested CFST specimens exhibited a significant yield plateau with demonstrated a relatively good ductile behavior. No tensile fracture was observed on the bottom flange of the outer steel tube. Clearly,
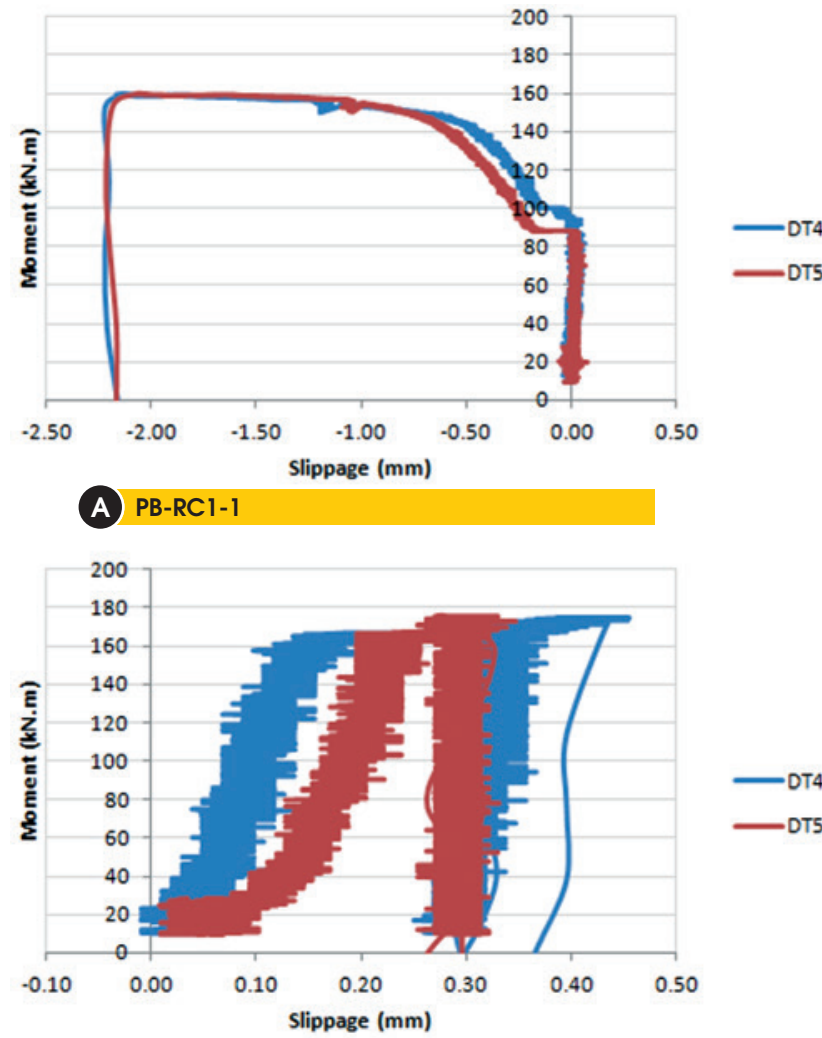

PB-RC2-1
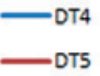

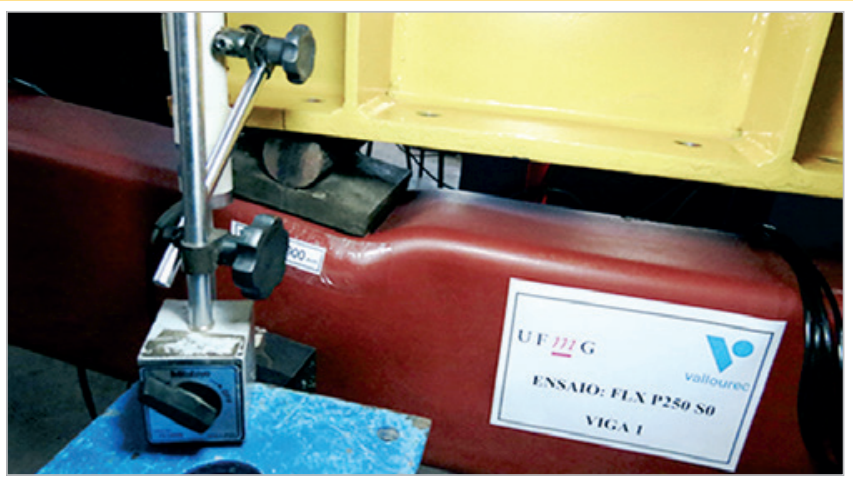

A $\mathrm{PB}-\mathrm{RC} 1-1$

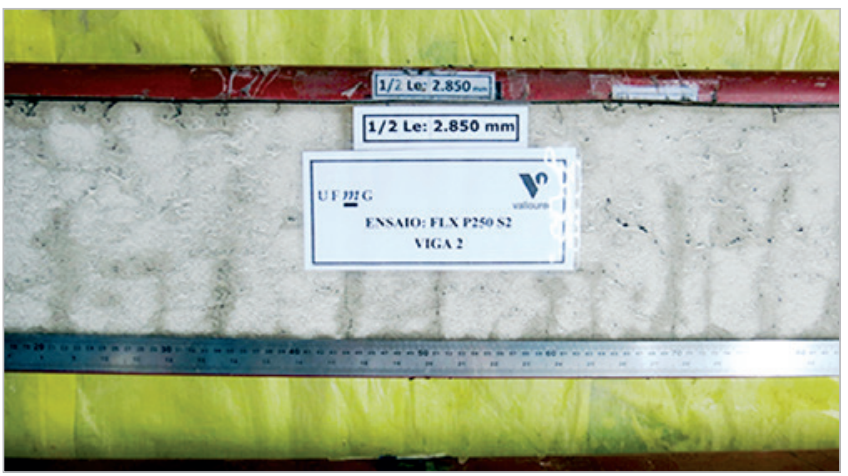

PB-RC2-2

Figure 16

Cracking pattern of CFST specimens

the infill of concrete enhanced the performance of the beam specimens probably due to the establishment of the composite action between the steel tube and the concrete core. After testing, part of the steel web within the neighborhood of the mid-span section was removed in order to investigate the cracking pattern of the concrete core, as shown in Figure 16. Fine cracks of the concrete core were observed in the tension area (bottom side of the specimen). The cracks distributed uniformly at the tension side of concrete along the pure bending segment of the CFST beams. No crushing of the concrete core was noticed near the compression area (upper side of the specimen).

Figure 17 shows the measured bending moment vs. slip relationship for each CFST beam specimen (series PB-RC1 and PB-RC2). The figure clearly shows that the slip measurements at

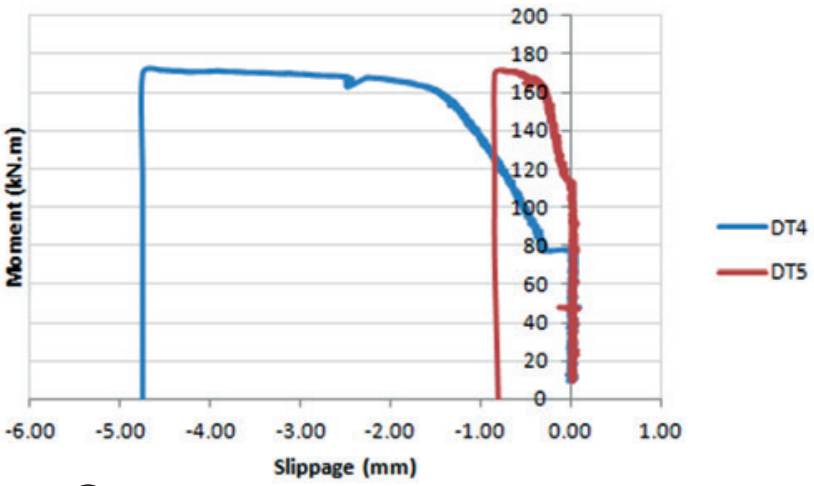

Figure 17

Moment vs. slip of CFST beam specimens

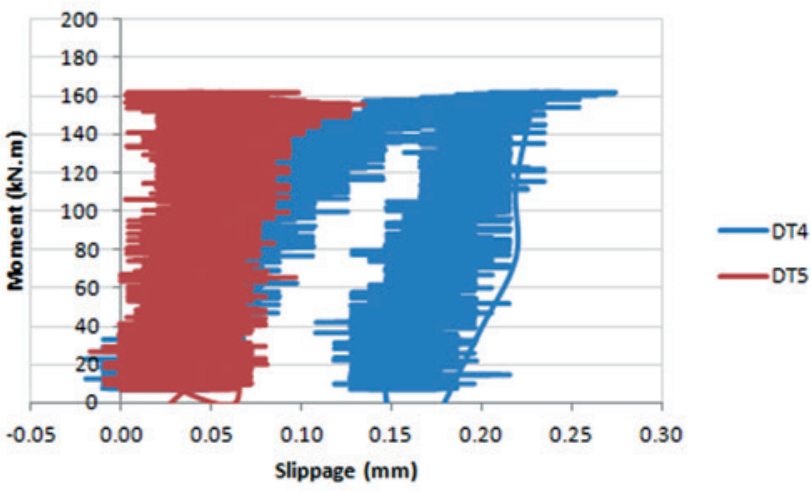

D PB-RC2-2 


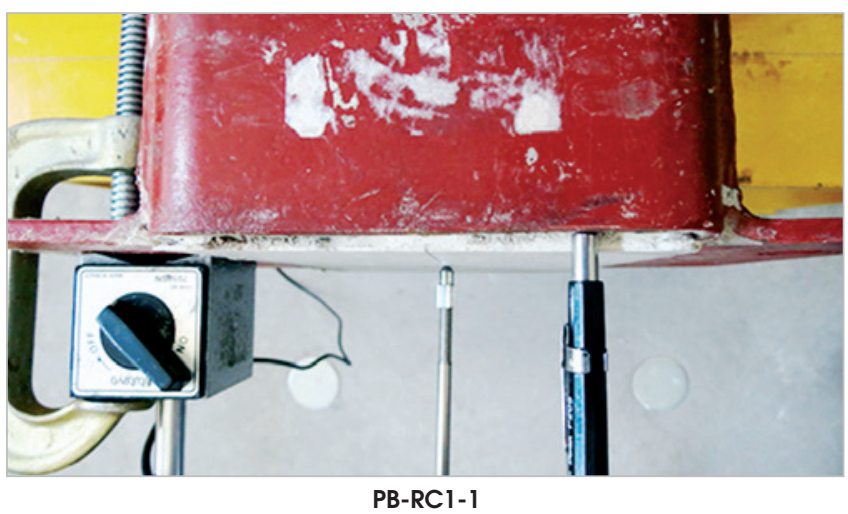

Figure 18

Slip between steel tube and concrete core

ultimate moment were significantly higher for the PB-RC1 series specimens. Slip values were as high as $5 \mathrm{~mm}$ approximately at the peak load (see Figure 18), which are substantially larger than the measured slip of the PB-RC2 series specimens (less than 0.5 $\mathrm{mm}$ ). This suggests that the association of anti-corrosive protective painting and wax-based coating was effective to minimize the adherence between the steel tube and concrete core. Additionally, the inner surface of the steel tubes of the untreated specimens of PB-RC2 series was rough and somewhat rusty enough to make negligible the relative slip between the two components. Despite differences in the measured slip values, there were no significant differences between the moment capacity measured for the PB$\mathrm{RC} 1$ and PB-RC2 series specimens. In other words, the slip was not detrimental to the composite action between the steel and the concrete of the CFST beams tested.

\section{Analysis and discussions}

\subsection{Theoretical predictions}

According to the Brazilian standards ABNT NBR 8800:2008 [16] and ABNT NBR 16239:2013 [17], the rectangular hollow steel (RHS) section used throughout the experiments is classified as a compact section with respect to Flange Local Buckling (FLB) and Web Local Buckling (WLB) ultimate limit states. Although the cross-section is not free from Lateral-Torsional Buckling (LTB), research results showed that the concrete core improves the buckling of the steel tube in torsion (Han et al. [2]) (Han et al. [18]). Therefore, assuming that no buckling will occur, the collapse of the composite beam will occur due to the plastification of the entire cross-section (formation of the plastic hinge) at the critical location and, consequently, the moment resistance will correspond to the plastic moment.

The ultimate moment capacities of both SHS and CFST beam specimens were predicted based on classical procedures from Solid Mechanics, i.e., the ultimate moment capacity was determined based on the plastic stress distribution with the following considerations. First, it was assumed full strain compatibility in the composite cross-section, i.e., full interaction between the steel tube and the concrete core. This assumption was based on the

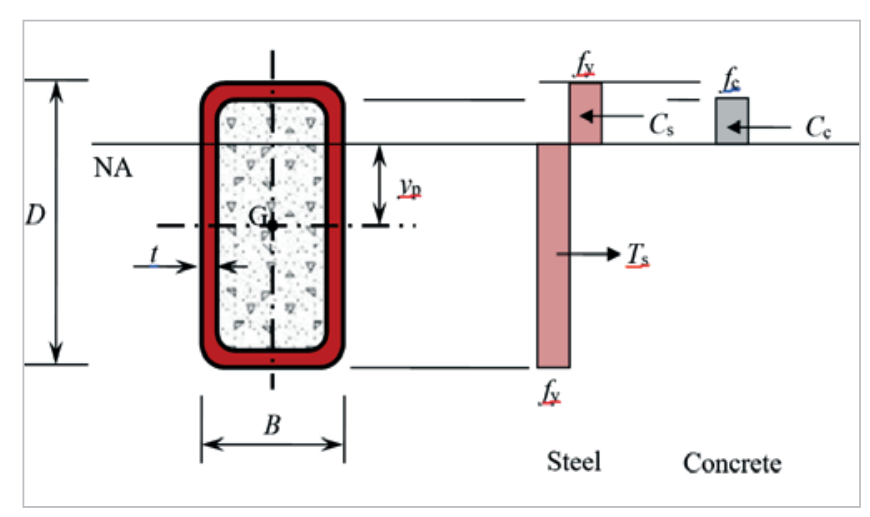

Figure 19

Plastic stress distribution for CFST beam specimens

negligible slip values measured in the flexural tests for the PB-RC2 series beam specimens. Second, since the actual material properties had been determined, the safety factors in the specifications were all set to unity so that the predicted values could be used for comparison with the experimental results. Third, the effective area of the steel tube is stressed to its yield strength $f_{\mathrm{y}}$ in tension or compression. Fourth, the effective area of the concrete core in compression is stressed to its cylinder compressive strength $f_{\mathrm{c}}$, constant over the whole depth between the plastic neutral axis and the most compressed fibre of the concrete. Fifth and finally, the tensile strength of concrete is neglected. Figure 19 illustrates the plastic stress distribution for the composite section. The resultant steel tensile and compressive forces $\left(T_{s}\right.$ and $C_{s}$, respectively) and the resultant concrete compressive force $\left(C_{c}\right)$, obtained by performing simple integration of the rectangular stress blocks over the corresponding area of steel and concrete are also shown in Figure 19. In this figure, "NA" denotes neutral axis and " $y_{p}$ " is the vertical distance of the neutral axis from the steel tube major axis.

It is worth noting that concrete-filled steel tube composite beams have not been dealt with by the Brazilian standards so far.

\subsection{Comparison of results}

Predicted moment capacities $\left(M_{\mathrm{p}}\right)$ are compared with the experimental results $\left(M_{\mathrm{e}}\right)$ in Table 2 . The experimental values include the contributions of the MTS actuator and the weight of both the beam specimen and the steel rigid beam. This table also shows both the mean value and the standard deviation of the ratio of $M_{p}$ to the corresponding $M_{e}$. A comparison of experimental moment capacities with the predicted moment capacities showed good agreement for the beams tested. Overall, the predicted moment capacity for the SHS beams was about $2 \%$ lower than that of test. For the CFST beams, the Brazilian design codes gave a moment capacity about $2 \%$ higher than that of the test.

For each series of specimens, the mean value of the experimental moment capacity $\left(M_{\mathrm{m}}\right)$ and its ratio to the moment capacity obtained for the SHS specimens $\left(M_{\text {ref }}\right)$, taken as reference, are listed in Table 2 as well. The results show that infilling the rectangular steel tube with concrete enabled an increase in the moment capacity of $14.4 \%$ and $16.4 \%$ for PB-RC1 and PB-RC2 series, 
Table 2

Comparisons between predicted moment capacities and test results

\begin{tabular}{|c|c|c|c|c|c|c|c|c|}
\hline $\begin{array}{l}\text { Specimen } \\
\text { designation }\end{array}$ & $\begin{array}{c}\text { Age } \\
\text { (days) }\end{array}$ & $\begin{array}{c}f_{c} \\
(M P a)\end{array}$ & $\begin{array}{c}E_{c} \\
(M P a)\end{array}$ & $\begin{array}{c}M_{p} \\
(k N \cdot m)\end{array}$ & $\begin{array}{c}\mathrm{M}_{\mathrm{e}} \\
(\mathrm{kN} \cdot \mathrm{m})\end{array}$ & $\frac{M_{p}}{M_{e}}$ & $\underset{(k N . m)}{M_{m}}$ & $\frac{M_{m}}{M_{r e f}}$ \\
\hline PB-RH1-1 & 190 & - & - & 147.87 & 150.67 & 0.981 & 150.89 & 1.000 \\
\hline PB-RH1-2 & 188 & - & - & 147.87 & 151.11 & 0.979 & - & - \\
\hline & & & & \multicolumn{2}{|r|}{ Mean } & 0.980 & & \\
\hline & & & & \multicolumn{2}{|c|}{ Standard deviation } & 0.002 & & \\
\hline
\end{tabular}

\begin{tabular}{|c|c|c|c|c|c|c|c|c|}
\hline $\begin{array}{c}\text { Specimen } \\
\text { designation }\end{array}$ & $\begin{array}{c}\text { Age } \\
\text { (days) }\end{array}$ & $\begin{array}{c}f_{c} \\
(M P a)\end{array}$ & $\begin{array}{c}E_{c} \\
(M P a)\end{array}$ & $\underset{(k N . m)}{M_{p}}$ & $\frac{\mathrm{M}_{\mathrm{e}}}{(\mathrm{kN} \cdot \mathrm{m})}$ & $\frac{M_{p}}{M_{e}}$ & $\underset{(k N . m)}{M_{m}}$ & $\frac{M_{m}}{M_{r e f}}$ \\
\hline PB-RC 1-1 & 136 & 47.28 & 37902 & 177.47 & 166.84 & 1.064 & 172.59 & 1.144 \\
\hline PB-RC 1-2 & 132 & 47.15 & 37850 & 177.41 & 178.33 & 0.995 & - & - \\
\hline PB-RC2-1 & 127 & 46.98 & 37780 & 177.34 & 182.12 & 0.974 & 175.63 & 1.164 \\
\hline PB-RC2-2 & 108 & 46.16 & 37449 & 176.99 & 169.14 & 1.046 & - & - \\
\hline & & & & & Mean & 1.020 & & \\
\hline & & & & \multicolumn{2}{|c|}{ Standard deviation } & 0.042 & & \\
\hline
\end{tabular}

respectively. It is noted that the treatment of the steel tube inner surface to minimize the adherence along the steel-concrete interface affected slightly the moment capacity of the CFST beams. The moment capacity of PB-RC1 series was about $2 \%$ lower than that of PB-RC2 series.

\section{Conclusions}

The following observations and conclusions can be drawn based on the limited research reported in the paper:

Self-consolidating concrete shows to be an effective concrete mix to infill horizontally large-scale rectangular steel tubes having length up to $12 \mathrm{~m}$. The use of pressure during casting shows to be an efficient method to pour concrete into the steel tubes.

Initial concrete imperfections, also named gaps, are expected to occur on the top surface of the concrete core whenever casting is made with rectangular CFST beams positioned horizontally. The influence of such gaps on the flexural behavior and performance of rectangular CFST beams shall be further investigated.

The infill of concrete changes the flexural behavior of the outer steel tube. While SHS beam specimens failed due to a plastic inward ripple in the compressive zone underneath the loading point, the CFST beam specimens behaved in a relatively ductile manner.

The infill of concrete enhances the flexural performance of SHS beam specimens. In average, the moment capacity of CFST beam specimens was about $15 \%$ higher than that of the unfilled steel tube beams.

The rigid-plastic theory shows to be appropriate to predict the moment capacity of CFST compact beams. For the tested CFST beams, the predicted moment capacity was about $2 \%$ higher than the experimental flexural capacity.
The association of anti-corrosive protective paint and mold release wax-based agent is effective to minimize the adherence along the steel-concrete interface of CFST beam specimens. The investigation of the worst case scenario for the composite action of the steel tube and the concrete core due to loss of adherence showed that minimum adherence along the steelconcrete interface had a slight effect on the moment capacity for 6-m long rectangular CFST beams with shear span-to-depth ratio as large as 7.6.

Further experimental work of this on-going research shall be conducted on CFST beams specimens with internal steel reinforcement and with a solid concrete slab placed on top of the tubular steel profile to investigate the structural behavior of large-scale rectangular CFST beams with different cross-section configurations.

This research also comprises a numerical analysis of the structural behavior of rectangular CFST beams based on a finite element model developed with the commercial software, Abaqus (Simulia [19]). The experimental data of this study and testing data reported by other researchers shall be used to calibrate the numerical model. The finite element model shall be used in a parametric study to investigate the influence of important parameters that determine the moment capacity of the composite beams.

\section{Acknowledgements}

The authors are grateful to Vallourec Tubos do Brasil S.A. for providing all the steel tubes in the experimental programme. Thanks are given to LafargeHolcim for providing the ready-mixed self-consolidating concrete. The financial support of the National Council for Scientific and Technological Development (CNPq) and Foundation for Research Support of Minas Gerais (FAPEMIG) are acknowledged. 


\section{References}

[1] EUROPEAN COMMITTEE FOR STANDARDIZATION. EN 1994-1-1: Eurocode 4 - Design of composite steel and concrete structures - Part 1-1: General rules and rules for buildings. Brussels, 2004.

[2] HAN, L.-H.; LI, L. and BJORHOVDE, R. Developments and advanced applications of concrete-filled tubular (CFST) structures: members. Journal of Constructional Steel Research, v. 100, p. 211-228, 2014.

[3] LU, Y.Q. and KENNEDY, D.J.L. The flexural behaviour of concrete-filled hollow structural sections. Canadian Journal of Civil Engineering, v. 21, n. 1, p. 111-130, 1994.

[4] ELCHALAKANI, M.; ZHAO, X.L. and GRZEBIETA, R.H. Concrete-filled circular steel tubes subjected to pure bending. Journal of Constructional Steel Research, v. 57, p. 11411168,2001

[5] GHO, W.-M. and LIU, D. Flexural behaviour of high-strength rectangular concrete-filled steel hollow sections. Journal of Constructional Steel Research, v. 60, p. 1681-1696, 2004.

[6] HAN, L.-H. Flexural behaviour of concrete-filled steel tubes. Journal of Constructional Steel Research, v. 60, p. 313-337, 2004

[7] HAN, L.-H.; LU, H.; YAO, G.-H. and LIAO, F.-Y. Further study on the flexural behaviour of concrete-filled steel tubes. Journal of Constructional Steel Research, v. 62, p. 554-565, 2006.

[8] LU, H.; HAN, L.-H.; and ZHAO, X.-L.. Analytical behavior of circular concrete-filled thin-walled steel tubes subjected to bending. Thin-walled Structures, v. 47, p. 346-358, 2009.

[9] MOON, J.; ROEDER, C.W.; LEHMAN; D.E.; and LEE, H.E. Analytical modeling of bending of circular concrete-filled steel tubes. Engineering Structures, v. 42, p. 349-361, 2012

[10] JIANG, A.; CHEN, J. and JIN, W. Experimental investigation and design of thin-walled concrete-filled steel tubes subject to bending. Thin-walled Structures, v. 63, p. 44-50, 2013.

[11] WANG, R.; HAN, L.-H.; NIE, J-G.; and ZHAO, X.-L. Flexural performance of rectangular CFST members. Thin-walled Structures, v. 79, p. 154-165, 2014

[12] LIAO, F.-Y., HAN, L.-H., and HE, S.-H. Behavior of CFST short column and beam with initial concrete imperfection: Experiments. Journal of Constructional Steel Research, v. 67, p. 1922-1935., 2009.

[13] ASSOCIAÇÃO BRASILEIRA DE NORMAS TÉCNICAS. ABNT NBR 15823-1:2010 Concreto auto-adensável Parte 1: Classificação, controle e aceitação no estado fresco . Rio de Janeiro, 2010.

[14] ASSOCIAÇÃO BRASILEIRA DE NORMAS TÉCNICAS. ABNT NBR 5739:2007 Concreto - Ensaios de compressão de corpos de prova cilíndricos. Rio de Janeiro, 2007.

[15] ASSOCIAÇÃO BRASILEIRA DE NORMAS TÉCNICAS. ABNT NBR 8522:2008 Concreto - Determinação do módulo estático de elasticidade à compressão. Rio de Janeiro, 2008.

[16] ASSOCIAÇÃO BRASILEIRA DE NORMAS TÉCNICAS. ABNT NBR 8800:2008 Projeto de estruturas de aço e de estruturas mistas de aço e concreto de edifícios. Rio de Janeiro, 2008.

[17] ASSOCIAÇÃO BRASILEIRA DE NORMAS TÉCNICAS. ABNT NBR 16239:2013 Projeto de estruturas de aço e de estruturas mistas de aço e concreto de edificações com perfis tubulares. Rio de Janeiro, 2013.

[18] HAN, L.-H.; YAO, G.-H. and TAO, Z.. Performance of concrete-filled thin-walled steel tubes under pure torsion. Thinwalled Structures, v. 45, p. 24-36, 2007.

[19] SIMULIA. Abaqus user's manual. Version 6.11. Dassault Systèmes: Providence, RI, USA; 2011. 